determine more precisely their mutual relations. It is here, again, gentlemen, that the knowledge that you bring from many parts of the world may aid us in throwing light on this difficult subject.

Amon $x$ the other questions which preceding Congresses have not decided, are :-

(I) The relation between the Carboniferous and the Permian.

(2) Between the Rhretic and the Jurassic.

(3) Between the Tertiary and the Quaternary.

When there is no interruption in the continuity of the strata, and no discordant stratification, the systems pass one into another without apparent break, like the colours of the solar spectrum; but, as you all know, if one link is wanting, the chain is broken, and the line of separation of the disunited beds becomes sharply defined. If, for example, the Caradoc should be absent in the Cambrian-Silurian, or the Pliocene should be wanting in the Tertiary, there would be between these systems a break which would give the necessary relief to the superimposed strata. The primary colours of the spectrum are not less distinctive because they pass one into the other with intermediate shades; nor does it follow that, because there are passage-beds, the systems form one whole. Thare must be, somewhere, passage-beds between them, as there are between the colours.

Apart from these international questions, the Berlin Congress was occupied with several special memoirs, but we are yet without particulars, and besides, whatever may be their interest, they concern us less for the moment than international questions. Among others of the latter, a great palæontological project ha been mooted, and the Congress has appointed a Commission of distinguished palæontologists to co-operate towards its realization. A work is proposed, on the plan of the "Enumerator et Nomenclator" of Brown, and of the "Prodrome" of Alcide d'Orbigny ; but such is the progress that palieontology has made, that at present, for the enumeration of all the known fossils, of animals as well as plants, a publication of some fifteen large volumes would be required. A work of this kind will make a handsome pendant to the large polyglot dictionary of geological terms, projected at Bologna.

Such, gentlemen, are some of the questions and subjects that you have to consider. You have to revise and to settle, when possible, questions already discussed, and also to discuss new problems. Among the latter there is especially the fundamental question of the crystalline schists-a subject remarkable for the great progress that it ha: made during the last few years, and the entirely new aspect that it is assuming; for it is evident at present that it is not only a chemical question of metamorphism by heat, but that it is a subject which entails questions of weight, pressure, and motion, which necessitate a wide co-operation, and the cumbined efforts of the physicist, the chemist, the petrologist, and the stratigraphist.

Although the greater number of the subjects considered by the Congress are eminently practical and positive, they also in clude theoretical questions of the highest interest. The classification of the strata and their synchronism over great areas, which you have to determine, rest both upon stratigraphy and upon palicontology. In order to adjust their precise relation, you have to note the identitjes as well as the differences of fossi species, and to know if the order of the beds in distant countries follows a synchronous order or is only homotaxial. In the one case, we can hardly expect to find similar species; in the other, the identity of species may be taken as a proof to the contrary, unless it may be suppoied, as Edward Forbes thought, that species have had more than one centre of origin.

To solve these problems you have to trace the dawn of life, the appearance, the duration, and the disappearance of species, and the source from which they come. Are we to believe in the evolution of species, or are we to regard them as shoots of short duration, and the genera or families as the branches or permanent trunks? If I have ventured to touch upon these problems of fact and theory, it is not to express an opinion, but merely to point out how vast the field is, and how many fellow-labourers and how long is the time required to inake all the necessary studies.

It must not be thought that when the fundamental questions of fact are determined the work of the Congress approaches completion. General agreement on these international questions will only smooth the way, and one can foresee in the cosmopolitan problems of theory already considered, and in many others that cannot fail to arise, what will occupy in a long and useful future all the efforts of this International Congress.

\section{ON THE CONSTITUTION AND STRUCTURE} OF THE CRYSTALLINE SCHISTS OF THE WESTER N ALPS. ${ }^{1}$

TEN years have elapsed since Prof. Lory first formulated his views on the crystalline schists of the Western Alps, at the Congrès International de Géologie held in Paris in 1878 . These he subsequently developed at the Réanion de la Société Géo. logique de France at Grenoble in I88I. Since then further work in the field has strikingly confirmed these views, and Prof. Lory has taken alvantage of the opportunity given by the invitation of the Organizing Committee of the Geological Congress to summarize briefly the more important facts, derived from the study of the Western Alps, that have a direct bearing on the general question of the crystalline schists.

The crystalline schists appear in the Alps in massifs of greater or less extent, protruding through the sedimentary formations. These massifs are distributed in two principal zones, arched in agreement with the general curvature of the Alps. These the author proposes to designate the first Alpine zone, or Mont-Blanc zone, and the fourth Alpine zone, or Monte-Rosa zone. The intermediate zones (se ond and third Alpine zones) are of less importance, the outcrops being rare and of small extent. As they resemble the fourth zone in their principal characters, they are treated in its connection.

(I) The fourth Alpine zonz, or sone of Monte-Rosa, is by far the largest. In it the crystalline schists are exposed over the greater part of the Italian slopes, and skirt the plain from Cuneo to Lake Maggiore. Their stratification is often nearly horizontal, and always conformable with the sedimentary formations (Trias or Jura) resting upon them.

It is subsequent to the deposition of these Secondary rocks and, very probably, even much later-in Tertiary times-that this part of the Alps has been fashioned into mountains by the lateral pressure resulting from the gradual subsidence of the vast regions represented by the plains of Italy and the basin of the Adriatic. The result of these $\mathrm{i}$ oportant dynamic processes was the formation of a complex of great folds, which are often much complicated by faulting.

The succession of the different groups of crystalline schists in this zone is conformable to the order indicated, long since, by Corclier. It is necessary to point ont, however, that this upper group-that of the talcites (talc-schists)-contains talc only as an accessory constituent; the unctuous (talcoid) aspect being due, in reality, to the presence of certain indistinctly cleavab!e and fibrous varieties of mica, especially sericite. These schists may be termed sericite-schists or, ahbreviated, serischists. In the purer varieties they are of a nacreous white or clear gray colour ; but by the addition of chlorite they a:sume greenish tints and pas into chloritic and quartzose schists - the chloritoschists which attain so great a development in the whole of the Western Alps. Alternating frequently with these rocks are hornblendic schists, of which the development is very variable. In certain parts of the Italian AIps, however, especially between Ivrea and Domo d'Ossola, they become predominant.

This upper division of the crystalline schists is characterized by a more or less pronounced green tint, due to the presence of chlorite or hornblende, which recalls the name pietre verdi, given to these and other schists by Gastaldi and several other Italian geologists.

Below the chloritic and hornblendic schists occurs a large series of mica-schists, with which are intercalated, in conform. able bedding, cipolin-limestones (caliaires cipolins), granular dolomites, and pure saccharoidal limestones, alternating with mica-schists and evidently forming part of the same formation.

The mica-schists become charged with felspar and pass thus into gneiss, with which they alternate. IBlack and white micas are a-sociated in these rocks. In proportion as the series is descended, orthoclase becomes more abundant, and the gneisses predominate with a foliation which decreases until they pass into granitoid gneiss, in which the foliation disappears, but the broader features of stratification remain vi-ible. This is well shown in the section of the Simplon massif, where the gorges of the Diveria are hollowed out, to a depth of 700 metres, in the horizontal beds of the granitoid gneiss known as the gneiss of Antigorio.

1 "Sur la Constitution et la Structure des Massifs de Schistes Cristallins des Alpes Occidentales," par M le Professeur Ch. Lory. "Ecudes sur les Schistes Cristallins," London, I888. (Abstracted from the French by Dr. F. H. Hatch.) 
Prof. Lory does not recognize in the Monte. Rosa zone any beds belonging to the Carboniferous; and he believes that the crystalline schists of this part of the AIps have been exposed during the whole of Palizozo:c times, without having been disturbed from their primitive horizontal position. They have gradually subsided during the Triassic period. The lower stages of this formation are not much developed in this zone; but the upper stage, represented by the scliste's lustrés, have acquired an enormous thickness.

These Triassic beds are characterized by a remarkably crystalline texture. The limestones and dolomites which form the middle stage are granular and saccharoidal, and inclose authigenic crystals of albite. The schistes lustris are composed in great part of crystallized minerals (quartz, mica, tourmaline, garnets, \&c.), which are also certainly authigenic. This crystalline condition is uniform and constant, and independent of all dislocations and crntortions which the beds have subsequently undergone.

The crystalline character of the sedimentary formations may be of assistance in understanding the origin of the crystalline schists. The foliation is generally parallel to stratification, the latter being always very distinct. Characters so uniform cannot be explained by the phenomena of slaty cleavage and crystallization under the influence of Jocal mechanical actions. It is rather a general, universal, and original crystallization of the primitive rocks, which took place anterior to the deposit of all sedimentary formations.

The most important element of Prof. Lory's third zonze are anthracitic sandstones. These sandstones helong to the Upper Coal-measures (houiller supurieur). The boundary between them and the crystalline schists is usually marked by a fault. But sometimes, as at the bridge of St. André, near the railway station at Modane, the latter appear under the sandstones, and then the foliation of the crystalline schists is conformable with the bedding of the Carboniferous sandstones. At this and other localities there occur in the lower portions of these sandstones conglomerates formed of slightly rolled fragments of crystalline schists, identical with those which crop out in the neighbourhood. It is therefore evident that the foliation and cry-tallization of the crystalline schists must be earlier than the Carboniferous period. Conglomerates, composed of fragments of the most diversified rocks from the crystalline schists, occur in the Upper Trias, in the Lias (Col du Golet), and in the Nummulitic Eocene (massif des Encombres). Each of these conglomerates contains fragments of all the preceding formations. Since these rolled pebbles have the characteristic structure, crystalline or foliated, of the rocks they are derived from, and since the foliation of the pebthles has no uniform direciinn in the conglomerates, it follows that the foliated or crystalline texture of the rocks of these various formations is, eaclı for each, of earlier origin than the deposition of that which overlies it, and absolutely independent of the powerful mechanical actions which only fashioned these formations into mountains subsequently to the Eocene per iod.

Again, all the formations, from the Trias to the Eocene, gontain microscopic crystals of silicates (felspars, mica, quartz, tourmaline), which are of contemporaneous origin with the rocks containing them, and do not, therefore, owe their existence to any of the dynamic processes which have subsequently acted fipon this part of the AIps.

Since these silicates, which are identical with, or very analogous to, those of the crystalline schists, were formed in the Secondary and Terliary deposits indefendently of al eruptive actions or special emanations, and anteriorly to al dynamic processes, it is unnecessary for the explanation of the origin of the primitive crystalline schist's to assume physical conditions absolutely different from those of the Secondary or Tertiary periods.

In the remote epoch in which these schists were formed there were no terrestrial features, and consequently no detrital formations. The existence of organisms in a universal ocean, warmer and more heavily charged with saline matters than actual seas, was not yet possible; and there resulted combinations of crystallized minerals, the forwation of which in later times became more local and restricted. But even as late as Tertiary times we still find traces of analogous reactions in the deposits of those remarkable fiords of the Eocene period which extend over a part of the actual site of our Alpine chains.

(2) Prof. Lory's first Alpine zone, or Mont-Blane zone, comprises, in Switzerland, the mas ifs of the Bernese Alps and of St. Gothard; in Savoy, those of the Aiguilles Rouges and of MontBlanc; the chain of Belledonne; the small massif of Rocheray, near St.-Tean-de-Maurienne ; the massif of Rousses, in Oisans ; the massif of Pelvoux, between Drac and Durance; finally, the massif of the Maritimes Alps, between the Col de l'Argentière and the Col de Tende.

The characteristic feature common to all these massifs consists in the crystalline schists composing them being nearly always highly inclined or almost vertical. They do not appear to present the regular structure-the great anticlinal folds of the Monte Rosazone. This indicates that the Mont-Blanc zone is really the ancient part of the orogenic system of the Alps, and that its structure has resulted from the dislocations of different epochs.

Anthracitic sandstones occur also in this zone, but they are less developed and less continuous than in the third zone, and, as indicated by their plant remains, are of more recent date, being intermediale between the Coal-measures of Rive-de-Gier and those of Saint-Etienne.

On the riestern slope of this zone traces of dislocations, anterior to the deposition of these Carboniferous sandstones, can be recognized. They are indicated by clear unconformities at various points in the Mure basin and other places. But on the eastern slope of the same zone the Carboniferous sandstones and the crystalline schists are generally conformable.

These Carboniferous sandstones of the first zone, like those of the third, are accompanied by conglomerates containing numerous fragments of foliated crystalline schists, of which the petrographical characters are identical with those of the underlying crystalline rocks. These conglomerates are well known on both western and eastern slopes (poudingues of Va!orsine, GrandesRousses, \&c.) Since the Carboniferous sandstone on the eastern slope is conformable with the crystalline schists, the existence of large fragments of the schists in these conglomerates, clearly demonstrates that their foliation is anterior to all dislocations which have affected the massif. It was after the deposition of the anthracitic sandstone, between the Carboniferous and Triassic periods, that the principal dislocations took place, which have upheaved and contorted the crystalline schists and the anthracitic sandstones of the first zone. Wherever the Triassic beds appear nearly horizontal they rest, in conformable stratification, on the upturned edges of the older formations, whether anthracitic sandstones or crystalline schists.

The horizontal position of numerous shreds of Secondary rocks to be found at very variable heights indicates the character of the dislocations which have taken place at more recent periokls in this part of the Alps. The ancient formations, already upheaved and contorted before the deposition of the Trias, have behaved like rigid masses, and have not lent themselves to the newer folding. They have been traversed by faults; and displacements have taken place along the plane; of fracture, while at the same time following the divisional plares of stratification. The Secondary rocks, on the other hand, have behaved like flexible, and even, when argillaceous, like plastic bodies. They have only been completely fractured by the more important major faults; everywhere they have moulded themselves by multiplex folding to the new forms of their dislocated base. This flexible covering has slipped into the depressions formed by the subsidence, due to dislocation, of certain parts of its base. In this way the Secondary rocks pre. sent themselves on the flanks of the Alpine valleys in beds which are inclined and contorted in repeated folds, contrasting thus with the uniform curvature of the ancient rocks.

The powerful mechanical actions resulting from these disloca. tions of the first Alpine zone have often superinduced, in the argillaceous limestones of the Lias, phenomena of "stretching," lamination, and, above all, a slaty cleavage in a direction different from that of stratification. As to the crystalline schists, of which the plication took place at the end of the Carboniferous asd before the Triassic period, the more recent dislocations have destroyed the regularity of their anticlinal and synclinal folds. Along the axes of the anticlinal ruptures, or following the bands of mica-schists - that part of the crystalline schists which offers least resistance-occurred the subsidences which have given rise to the actual Alpine valleys ; it is following these directions, and nearly always following the old synclinal folds, that the ancient rocks have been cut up into massifs, separated by the bands of depression, where the Secondary rocks, adapting themselves to the new forms assumed by their base, have descended while undergoing plication; and their beds, highly inclined and often curiously folded, clothe the lateral walls of these depressions. The valley of Chamonix and l'Allée Blanche, the Combe d'Olle, the lower valley of the same stream, at Allemont, and that of Bourg-d'Oisans, are examples of this type of longitudinal Alpine valleys of the Mont-Blanc zone. 
The massifs of crystalline schists represented in this zone are large remnants which have remained standing in ruins, the other parts of the primitive rocks having subsided either en masse; following great faults, or in detail, by a series of small slides, following the numerous joints, or the divisional planes of bedding. Not one of them represents a regular and complete anticlinal fold.

The various types of crystalline schist comprised in the MontBlanc zone succeeded one another in the same order as in the Monte-Rosa zone. They are also divided into two groups: the upper group-sericitic, chloritic, and hornblendic schists; and the lower group-mica-schists and true gneisses.

In the lower group there is a tendency towards the granitoid structure, and the rocks appear more or less massive, but yet in the main stratiform. They become rich in white mica, and assume a granulitic texture. These phenomena are developed along the anticlinal axes.

The crystalline schists of the npper group have a tendency to become richer in felspar the nearer one approaches the intraAlpine limit of the zone. It seems that this corresponds with the direction in which alkaline emissions, accompanying the formation of these rocks, took place, the same direction afterwards becoming that of the great limiting fault of the zone. The schists pass thus into chloritic gneisses similar to those occurring near the station at Modane (third zone), or to the gneiss of Arolla (fourth zone) ; sometimes also into granitoid gneisses, both chloritic and hornblendic, as, for instance, at Cevins, in Tarantaise.

The tenacity of the chloritic and hornblendic schists, which is generally much superior to that of the mica-schists and true gneisses, and their tendency to develop felspar, which gives them greater consistency, explain the important role played by these rocks in the constitution of the culminating ridges and steeper massifs of the first zone. In the Mont-Blanc massif and in the eastern portion of the Pelvoux massif these "needles" and abruptly culminating ridges characterize the type of rock known as protogine. This name, the etymological sense of which must be forgotten, has been created to designate the type of rocks which predominates in the principal ridge of Mont-Blanc. The special character of these rocks consists in the mica being penetrated and partly replaced by chlorite. The granitoid protogine always contains two felspars-orthoclase and oligoclase, part of the orthoclase being usually replaced by microcline.

Prof. Lory thinks the protogine belongs to the upper groupthat of the chloritic schists. In that case Mont-Blanc cannot be regarded as a central arch of elevation, and its "fan-structure" becomes simply a very sharp synclinal fold of the crystalline schists of the upper group, isolated by two faults, along which they have subsided, while acquiring a U-shaped fold.

In the Pelvoux-massif the protogine is even more largely developed than at Mont-Blanc. Here also it is stratiform, and alternates with chloritic gneisses like those of the western parts of the massif. A series of anticlinal and synclinal folds, can be made out. The anticlines correspond to the Vallon des Etages, the Barre des Escrins (west slope), and the Combe d'Alefroide; and the synclines to the Combe de la Pilatte, the eastern slope of the Escrins (Glacier Noir), and the summits of Mont-Pelvoux.

From observations made near Bourg-d'Oisans, the author arrives at the conclusion that the protogine has originated by a modification of the chloritic schists. During their formation, a considerable increase in their felspathic constituent was produced by granulitic emissions which took place through the gneiss and mica-schists.

Like other important features in the structure of the Eastern Alps this replacement of chloritic schists by protogine follows the intra-Alpine limit of the Mont-Blanc zone, which limit is marked by the great fault-line which can be traced over 60 lieues, from Vallonise to Airolo. This must have been the direction in which took place those granulitic emissions, which, withou giving birth to true eruptive masses, have modified the character of the old gneiss and mica-schists and developed in the chloritic and hornblendic schists the felspathic character which dis tinguishes the granitoid rock known as protogine.

THE ELECTRIC TRANSMISSION OF POWER. ${ }^{1}$

WHAT is power, and why should we wish to transmit it? Power has one very definite meaning in science, and several rather vague meanings in practice. We speak of a

${ }^{1}$ Lecture delivered by Prof. Ayrton, F.R.S., at the Diill Hall, Path, on Friday, September 7, I888. powerful athlete, the power of the law ; we sing of the power of love; we say knowledge is power, and so on, using the word in several different senses. Now, in spite of the fact that a general audience feels a little anxious as to what troubles may be in store for it when a lecturer begins by being painfully exact, my telling you that by power an engineer understands the rate of doing work will not, I hope, make you fear that my remarks will bristle with technicalities.

When you walk upstairs you exert power-only, perhaps, the one-twentieth of a horse when you go up slowly, talking to other people. But when you run upstairs hecause you have forgotten something that you intended to bring down, then your exertions represent, perhaps, the one-tenth of a horse-power. You only get to the top of the stairs in either case, but the breathless sensation of running fast upstairs tells you that the more quickly you go the harder you are working. A person exercises power in the engineer's sense when he exerts himself physically, and the greater the exertion the greater the power. The exercise of power by the ruling classes, however, is unfortunately not necessarily accompanied by any exertion, physical or mental.

Probably the most familiar example of exerting power at a distance-that is, of transmitting power-is pulling a handle and ringing a bell in another room. I pull the handle, exerting myself slightly, and as the result the bell at the other end of the platform rings. Were not this such a very familiar operation I would call it experiment No. I. You have doubtless all of you performed this experiment several times to-day, and-what is all important with an experiment-performed it successfully.

And yet it was not until just one hundred years ago that it dawned on people that if one person, $\mathrm{A}$, wanted to attract the attention of another person, $\mathrm{B}$, the place where the bell ought to sound was where B was, and not where A was. Indeed, in many English villages down to the present day the knocker principle of attracting attention is alone resorted to, with the result which you may remember happened when Mr. Pickwick was staying in Bath at lodgings in the Royal Crescent, and $\mathrm{Mr}$ Dowler undertook to sit up for Mrs. Dowler, but " made up his mind that he would throw himself on the bed in the back room and think-not sleep, of course. . . . Just as the clock struck three there was blown into the crescent a sedan-chair with Mrs. Dowler inside, borne by one short fat chairman and one long thin one. . . They gave a good round double knock at the street door. . . ' 'Knock again, if you please,' said Mrs. Dowler, from the chair. 'Knock two or three times, if you please.' The short man stood on the step and gave four or five most startling double knocks of eight or ten knocks a-piece, while the long man went into the road and looked up at the windows for a light. Nobody came-it was as silent and as dark as ever." But the tall thin man, you may remember, "kept on perpetually knocking double knocks of two loud knocks each, like an insane postman," till $\mathrm{Mr}$. Winkle, waking up from a dream " that he was at a club where the cbairman was obliged to hammer the table a good deal to preserve order," met with the catastrophe which the readers of "Pickwick" will remember.

This episode shows what comes of having plenty of power and no means of transmitting it.

But if some houses can still dispense with mechanical or other methods of transmitting power, even to ring bells, factories cannot. The looms, the lathes, or whatever the machinery used in the factory may be, must either be worked by hand or foot in the old style, or it must be connected with the steam-, gas-, or waterengine in the new. On entering a large factory you see lines of rapidly-rotating shafting, and a net-work of rapidly-revolving belting, all employed in transmitting power. As a contrast to this, I now throw on the screen a photograph of Sir David Salomon's workshop at Tunbridge Wells, in which every machine is worked by a separate electric motor, thus saving to a great extent the loss of power that usually accompanies the mechanical transmission.

In America there are 6000 electromotors working machinery; in Great Britain hardly 100.

But it is not only in transmitting the power from the steam-, gas-, or water-engine of a factory to the various machines working in it, that electricity can be utilized. An incredible amount of power is daily running to waste in this and other countries because many of the rapid streams of water are too far away from towns for their power to have been hitherto utilized.

The holiday tourist, when admiring the splashing water dashing over the stones, hardly realizes that the money loss is as if the foam were composed of flakes of silver. 